\title{
Occupancy and population density estimates of the Amazonian manatee in eastern Ecuador
}

\author{
Viviana Narváez Ruano ${ }^{1}$, Victor Utreras B. ${ }^{2,3}$, Galo Zapata-Ríos ${ }^{1, *}$ \\ ${ }^{1}$ Wildlife Conservation Society, Ecuador Program, Mariana de Jesús E7-248 y La Pradera, Quito 170518, Ecuador \\ ${ }^{2}$ Ministerio del Ambiente de Ecuador, Madrid 1159 y Andalucía, Quito 170525, Ecuador \\ ${ }^{3}$ IUCN SSC Sirenia Specialist Group
}

\begin{abstract}
The Amazonian manatee Trichechus inunguis has been categorized as Vulnerable by the IUCN. There have been few studies on the species in its natural habitats due to its elusive nature and the low visibility of its aquatic habitats. Understanding the conservation status of Amazonian manatees, as well as any changes in their population trends and direct threats, is the basis for their management and conservation. Our study was carried out in 2 localities of the Ecuadorian Amazon (Tambococha-Jatuncocha and the Lagarto River), in the provinces of Sucumbíos and Orellana. We surveyed Amazonian manatees along rivers and in lagoons, using fish finder sidescan sonar to increase detectability rates. We estimated encounter rates, population density and occupancy. With a sampling effort of $573 \mathrm{~km}$, we obtained an average encounter rate of 0.90 records $10 \mathrm{~km}^{-1}$ and estimated a population density of 1.09 and 0.94 ind. $\mathrm{km}^{-2}$ in TambocochaJatuncocha and the Lagarto River, respectively. In addition, occupancy rates varied between 0.51 and 0.57, and presence and distribution of the species were associated with distance to humans. The Amazonian manatee population estimates presented here represent a baseline for future research, and additional surveys will be needed to understand population fluctuations over time. An evaluation of population viability in Tambococha-Jatuncocha and the Lagarto River would also be required to determine whether these populations will be able to persist over the long term under different deterministic and stochastic scenarios.
\end{abstract}

KEY WORDS: Sirenia · Amazonian manatee · Trichechus inunguis · Population density · Side-scan sonar · Ecuadorian Amazon

\section{INTRODUCTION}

The Amazonian manatee Trichechus inunguis is one of the 4 species of the order Sirenia. It occurs in freshwater only and is endemic to the Amazon basin in Colombia, Ecuador, Peru and Brazil (Best 1982, 1983, Reynolds et al. 2018). Its main habitats include rivers, lagoon systems and blackwater flooded plains, preferring calm waters with abundant aquatic vegetation (Best 1982, 1983, Reeves et al. 1996). Due to the anthropic threats the Amazonian manatee faces (e.g. hunting and habitat loss), it has been categorized as Vulnerable by the IUCN (Marmontel et al. 2016). There have been few studies on the Amazonian man-

${ }^{*}$ Corresponding author: gzapata@wcs.org atee in its natural habitats due to its declining population, elusive nature and the fact that it tends to spend most of its life underwater (e.g. Best 1983, 1984, Reynolds et al. 2018). This has also made it difficult to create a reliable method to estimate population variables such as abundance and population density. On the other hand, the aquatic habitats of the Amazonian manatee constitute a challenge for studying the species due to the dark color of the water, the amount of sediments and poor visibility. Thus, traditional methods for manatee observation, including direct observation from boats or small planes, have not been successful in the Amazon region. In this context, side-scan sonar constitutes a method with great po-

() The authors 2021. Open Access under Creative Commons by Attribution Licence. Use, distribution and reproduction are unrestricted. Authors and original publication must be credited. 
tential, as it has successfully detected other species of manatees (Gonzalez-Socoloske et al. 2009, GonzalezSocoloske \& Olivera-Gomez 2012). With this method, manatees can be detected in both clear waters (Gonzalez-Socoloske et al. 2009, Gonzalez-Socoloske \& Olivera-Gomez 2012) and black waters (ArévaloGonzález et al. 2014, Castelblanco-Martínez et al. 2018) with a high detection rate, varying between 70 and $80 \%$ (Gonzalez-Socoloske et al. 2009).

In Ecuador, the Amazonian manatee can be found in the northern areas of the Amazon region. Most records of this species have been made in the lagoon and river systems of the Cuyabeno and Lagarto (Denkinger 2010, Utreras et al. 2013). The species faces a series of threats in the country, such as hunting, habitat destruction and water pollution, and therefore it is considered by the Ecuadorian government to be critically endangered (Tirira 2011). However, the species has been poorly studied in Ecuador (Timm et al. 1986, Denkinger 2010, Brice 2014), and there is no information available to evaluate its true current conservation status in the country. Understanding the conservation status of wildlife species, as well as any changes in their population trends and direct threats, is the basis for their management and conservation (Gese 2001, Isasi-Catalá et al. 2016). To this end, our main objective was to use side-scan sonar to generate baseline information on encounter rates, population density and occupancy of the Amazonian manatee in 2 localities of the northern Ecuadorian Amazon. tween Ecuador and Peru. The Lagarto River consists of a series of blackwater lagoons, with small amounts of suspended sediments (Sierra 1999). Both survey sites are surrounded by blackwater-flooded forests, terra firme forests and tall flooded grasslands (Sierra 1999, Galacatos et al. 2004). Although precipitation occurs throughout the year, the dry season is usually between November and late February, while the rainy season is between April and July (Asanza 1985, Arroba Benítez 2011). The average annual temperature is $25^{\circ} \mathrm{C}$, total annual rainfall reaches $3000 \mathrm{~mm}$ and relative humidity exceeds $90 \%$ (Pourrut \& Pouyaud 1995).

\subsection{Manatee sampling}

In each of the 2 localities, surveys were carried out along rivers and in lagoons. Three surveys were carried out (over 5 consecutive days) in September 2016, January 2017 and November 2017. To significantly increase detectability rates, we used a fish finder side-scan sonar (Humminbird 999 ci HD, https:// www.humminbird.com/) powered by a $12 \mathrm{~V}$ car battery. The sonar uses sound waves to locate and define structure, bottom contour, bed composition and water depth; it releases sound wave signals both sideways and vertically from the canoe, determining distance by measuring the time between the transmission wave and when the sound wave is reflected off an object, and then uses the reflected signal to

\section{MATERIALS AND METHODS}

\subsection{Study area}

Amazonian manatees Trichechus inunguis were surveyed in 2 localities of the Ecuadorian Amazon, in the provinces of Sucumbíos and Orellana (Fig. 1). The first survey site was the lower Yasuní River, in the lagoons of Tambococha and Jatuncocha $\left(0^{\circ} 59^{\prime}\right.$ 39.3" S, 75²6' 46.99" W), in Yasuní National Park. Both sites are typical blackwater lakes with low sediment and nutrient contents, especially nitrogen (Asanza 1985). The second survey site was the Lagarto River $\left(0^{\circ} 38^{\prime}\right.$ 43.22" S, 75 14' 28.93" W), located along the eastern section of Cuyabeno Wildlife Reserve, at the border be-

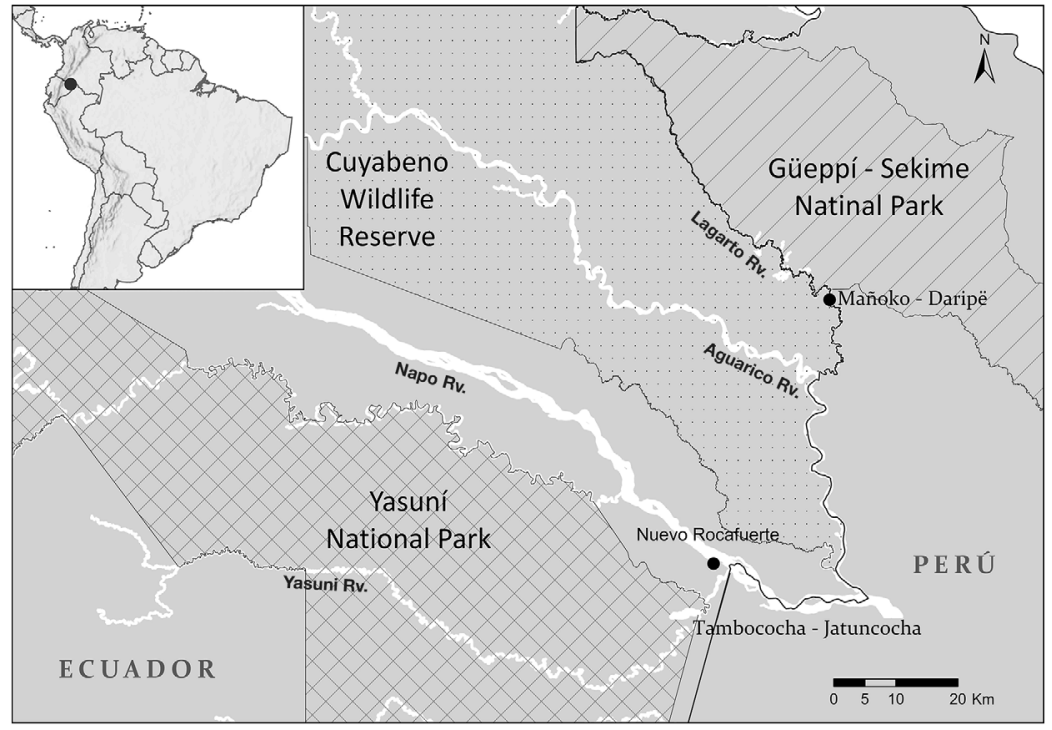

Fig. 1. Study area in the northern Ecuadorian Amazon. The location of human settlements, protected areas in Ecuador and Peru, Tambococha-Jatuncocha and the Lagarto River are shown 
interpret location, size and composition of objects. The sonar has a quad-beam system equipped with 2 lateral beams working at a frequency of $455 \mathrm{kHz}$ at an angle of $86^{\circ}$ and 2 vertical beams working at frequencies of $200 \mathrm{kHz}$ at an angle of $20^{\circ}$ and $83 \mathrm{kHz}$ at an angle of $60^{\circ}$ (Humminbird 2014). The frequency of the sounds emitted by the sonar is well above the hearing range of manatees, which varies between 6 and $20 \mathrm{kHz}$ (Gerstein et al. 1999, GonzalezSocoloske \& Olivera-Gomez 2012), causing no negative impact on the species. The sonar has a high manatee detection rate $(>80 \%)$, which makes it an effective tool to study the species (GonzalezSocoloske \& Olivera-Gomez 2012). Five $10 \mathrm{~km}$ transects were established at the Lagarto River, and 3 transects (of the same length) were established at Tambococha-Jatuncocha. Each transect was divided into 4 segments of $2.5 \mathrm{~km}$. The minimum separation between transects was $2.25 \mathrm{~km}$ (Fig. S1 in the Supplement at www.int-res.com/articles/suppl/n044 p105_supp.pdf). We navigated each transect on 3 different occasions during each visit to the 2 localities. For the best acoustic images, we navigated upriver in a small canoe (10 m long) at an average speed of $7 \mathrm{~km} \mathrm{~h}^{-1}$, travelling through the middle of the water body in rivers and following a zigzag pattern (also along the edges) in lagoons. Surveys took place between 05:00-12:00 and 14:00-18:00 h. During the surveys we also collected data on water depth and the location of flooded grasslands.

\subsection{Manatee identification}

We identified images of Amazonian manatee individuals following the recommendations provided by Gonzalez-Socoloske et al. (2009), taking into consideration their reflectivity, position, shadow and size. We verified our identifications of the species with the aid of 9 experts on manatees and sonar data (see 'Acknowledgements'). HumViewer v.86 free software (http://humviewer.cm-johansen.dk/) was used for manatee identification.

\subsection{Estimation of encounter rates and population density}

Encounter rates and $95 \%$ CIs of Amazonian manatees were estimated for every survey period and site using the number of Amazonian manatee records for every $10 \mathrm{~km}$ of survey effort. We considered each transect as the replicate unit for analysis (Carrillo et al. 2000, Reyna-Hurtado \& Tanner 2005). To estimate population density, for each Amazonian manatee record, we measured the radial distance and angle of observation using HumViewer v.86 software. Although the detection function was derived from data from both survey sites to improve estimation, population density for the species was estimated independently for the 2 survey sites using Distance 7.0 software. Population densities were estimated by applying uniform and half-normal key functions and cosine or simple polynomial adjustment terms as needed (Buckland et al. 2001, Thomas et al. 2010). Goodness-of-fit tests were used to assess whether assumptions of distance surveys were violated. In addition, we used Akaike's information criterion to choose the best model, considering model adjustment for distances nearing zero, as such distances provide more accurate population density estimations (Buckland et al. 2001).

\subsection{Estimation of occupancy rates}

Estimations of occupancy $(\psi)$ and detection $(p)$ probability for the Amazonian manatee were based on data from the first surveys carried out in September 2016. We created 2 capture histories, one for each survey site (MacKenzie et al. 2002), and applied single-species, single-season occupancy models (MacKenzie et al. 2002, 2006). We modeled occupancy with 3 site and 3 sampling covariables (Table 1; MacKenzie et al. 2002, 2006). Occupancy was modeled as a function of spatial heterogeneity found in each $2.5 \mathrm{~km}$ segment: (1) distance to the river mouth (D_RIV), measured as the Euclidean distance $(m)$ from the center of every segment to the point where the Lagarto River flows into the Aguarico River and the Yasuní River flows into the Napo River; (2) distance to settlements (D_SET), measured as the Euclidean distance $(\mathrm{m})$ from the center of every segment to the nearest settlement (the communities of Mañoko-Daripë for the Lagarto River and Nuevo Rocafuerte for Tambococha-Jatuncocha); and (3) area covered by flooded grassland $\left(\mathrm{km}^{2}\right)$ in a $1.5 \mathrm{~km}$ buffer from the center of every segment (GRASS). Flooded grasslands (Sierra 1999) are a type of vegetation which can grow up to $3 \mathrm{~m}$ tall, frequently occur as floating mats and are located at the edges of rivers and lagoons. They contain abundant organic compounds and are also one of the main sources of food for the Amazonian manatee (Timm et al. 1986, Tirira 2017). 
Table 1. Description of site and sampling covariables used for modeling Amazonian manatee occupancy $(\psi)$ and detection $(p)$

\begin{tabular}{|c|c|c|c|}
\hline $\begin{array}{l}\text { Covariate } \\
\text { description }\end{array}$ & $\begin{array}{l}\text { Para- } \\
\text { meter }\end{array}$ & Acronym & A priori prediction \\
\hline Distance to river mouth & $\psi(\mathrm{m})$ & D_RIV & Occupancy rates are higher farther from the river mouth \\
\hline Distance to human settlements & $\psi(\mathrm{m})$ & D_SET & Occupancy rates are higher farther from human settlements \\
\hline Area covered by flooded grassland & $\psi\left(\mathrm{km}^{2}\right)$ & GRASS & Occupancy rates are higher in areas covered with flooded grassland \\
\hline Water depth & $p(\mathrm{~m})$ & DEPTH & Detectability rates are higher in deep water \\
\hline Lagoon or river & $p$ & LAG_RIV & Detectability rates are lower in lagoons compared to rivers \\
\hline Distance to nearest food patch & $p(\mathrm{~m})$ & D FOOOD & Detectability rates are lower farther from the nearest food patch \\
\hline
\end{tabular}

On the other hand, detectability was modeled as a function of (1) water depth (DEPTH), measured as the average depth level (m) in every $2.5 \mathrm{~km}$ segment; (2) lagoon or river (LAG_RIV), a categorical variable which indicates whether the center of every segment was located in either a lagoon or a river; and (3) distance to the nearest food patch (D_FOOD), measured as the Euclidean distance $(\mathrm{m})$ from the center of every segment to the nearest flooded grassland patch.

Site and sampling covariables were measured from existing GIS layers on ArcGIS Desktop 10.7. Occupancy modeling was performed with Presence 12.0 software (Hines 2018). We modeled detection probability using the global model of occupancy, and the best detection models were used for modeling occupancy. For detectability and occupancy, we included an intercept model with no covariates among the set of candidate models, and for both survey sites, we constructed occupancy models with all single covariables. Values of Akaike's information criterion, corrected for small sample size, were used to rank candidate models (Burnham \& Anderson 2002). We calculated average occupancy and $95 \%$ CIs from the individual occupancy values in both survey sites $(\mathrm{n}=$ 12, Tambococha-Jatuncocha; $\mathrm{n}=20$, Lagarto River). We assessed the fit of our global models with a goodness-of-fit test based on the Pearson $\chi^{2}$ statistic and bootstrapping (MacKenzie \& Bailey 2004).

\section{RESULTS}

\subsection{Encounter rates and population density}

With a sampling effort of $573 \mathrm{~km}$, we obtained an encounter rate of 0.97 records $10 \mathrm{~km}^{-1}(95 \% \mathrm{CI}=$ \pm 0.19 ) in Tambococha-Jatuncocha and 0.84 records $10 \mathrm{~km}^{-1}(95 \% \mathrm{CI}= \pm 0.28)$ in the Lagarto River. In Tambococha-Jatuncocha, there were no significant differences in encounter rates between survey peri- ods. In the Lagarto River, on the other hand, there were significant differences between survey periods (Fig. 2). Also, there were no significant differences in encounter rates between the 2 survey sites (Fig. 2).

The estimated population density for the Amazonian manatee Trichechus inunguis in TambocochaJatuncocha was 1.09 ind. $\mathrm{km}^{-2}(95 \% \mathrm{CI}=0.83-1.45$; coefficient of variation $[\mathrm{CV}]=13.35 \%$ ), and for the Lagarto River, the population density was 0.94 ind. $\mathrm{km}^{-2}(95 \% \mathrm{CI}=0.68-1.29 ; \mathrm{CV}=15.91 \%)$. The detection function shows that detectability of the Amazonian manatee was greater between 5 and $10 \mathrm{~m}$ from the transect line (canoe), dropping off at 15 m (Fig. 3).

\subsection{Occupancy and detectability models}

No single model fully explained the observed patterns for Amazonian manatees. As a result, we model averaged across all candidate models to

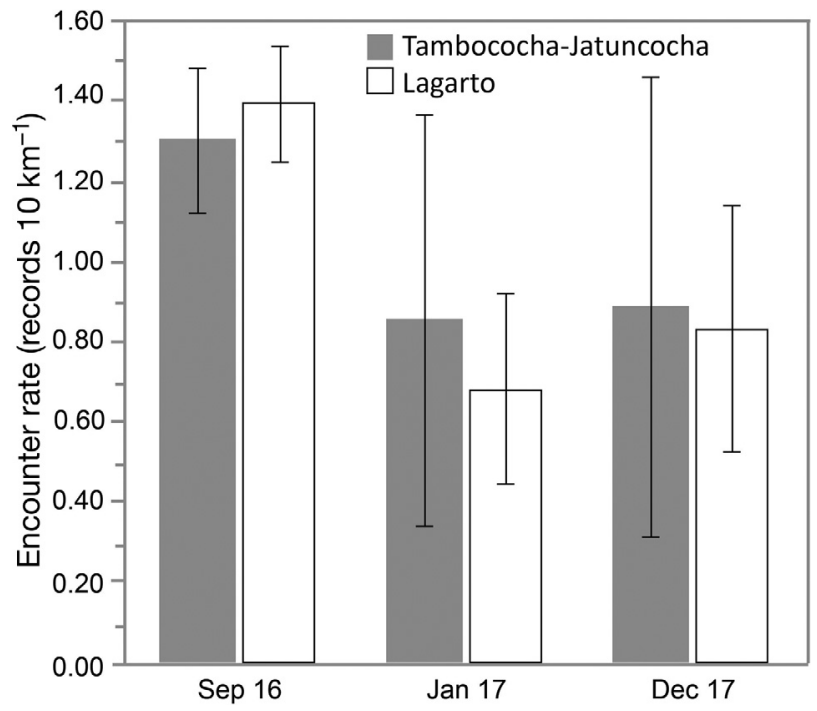

Fig. 2. Encounter rates of Amazonian manatees in 3 survey periods in 2 localities of the Ecuadorian Amazon (error bars are $95 \%$ CIs) 
obtain estimates of occupancy and detectability. Occupancy probability for the Amazonian manatee was estimated at $0.65 \pm 0.21$ (mean $\pm \mathrm{SE}$ ) for Tambococha-Jatuncocha and $0.57 \pm$ 0.22 for the Lagarto River. Detection probability was estimated at $0.51 \pm$ 0.07 for Tambococha-Jatuncocha and $0.48 \pm 0.17$ for the Lagarto River (Table 2).

In Tambococha-Jatuncocha, we did not find any significant effects of the site covariables on the occupancy of the Amazonian manatee. The null model was the most parsimonious one, followed by distance to settlements (Table 3). For the Lagarto River, distance to settlements and area covered by flooded grasslands had a significant effect on occupancy of the Amazonian manatee (Table 3). Distance to settlements and distance to the river mouth were positively associated with Amazonian manatee presence in both survey sites (Table 4). However, the relationship between occupancy and area covered by flooded grasslands varied from one site to another,

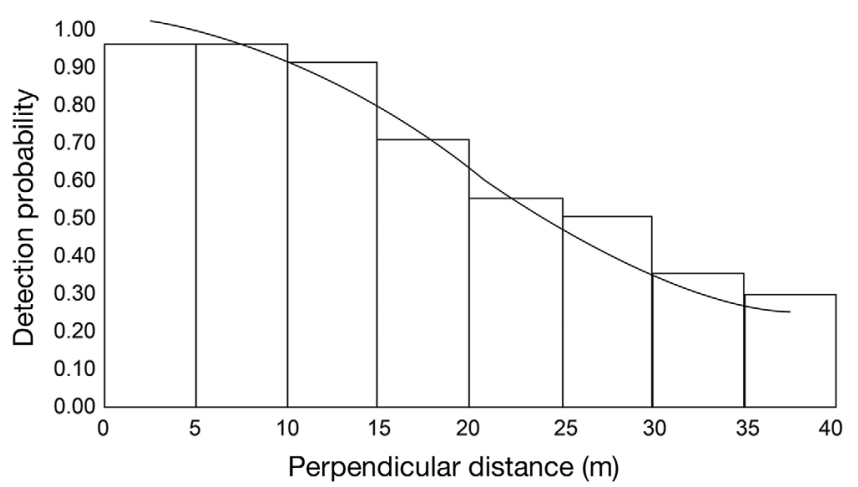

Fig. 3. Amazonian manatee records $(n=51)$ by perpendicular distance from the line transect and fit of the uniform model used to estimate the detection function, showing the probability of detecting an Amazonian manatee as a function of distance from the transect line

Table 2. Model-based parameter estimates of occupancy $(\hat{\psi})$ and detectability $(\hat{p})$, including SEs and CIs $( \pm 95 \% \mathrm{CI})$ for the Amazonian manatee in 2 localities of the Ecuadorian Amazon

\begin{tabular}{|lcccccc|}
\hline Survey site & $\hat{\psi}$ & SE & CI & $\hat{p}$ & SE & CI \\
\hline $\begin{array}{c}\text { Tambococha- } \\
\text { Jatuncocha } \\
\text { Lagarto River }\end{array}$ & 0.65 & 0.21 & 0.12 & 0.51 & 0.07 & 0.031 \\
\hline
\end{tabular}

showing a positive association in the Lagarto River and a negative one in Tambococha-Jatuncocha (Table 4).

Distance to settlements had a significant effect on occupancy of Amazonian manatees in TambocochaJatuncocha and the Lagarto River (cumulative model weight, $w+=0.32, \beta=6.08, \mathrm{SE}=8.55$ and $w+=0.48$, $\beta=0.49$, SE $=0.68$, respectively). For TambocochaJatuncocha, the models for global detection and distance to the closest food patch had a basically identical weight, which suggests that both covariables determined the detectability of Amazonian manatees. We were unable to find a covariable which would conclusively explain detectability of the species at this site. In the Lagarto River, the detection probability for the Amazonian manatee was determined by water depth. The goodness-of-fit tests did not suggest any lack of adjustment in the models for TambocochaJatuncocha and the Lagarto River $\left(\chi^{2}=12.69, \mathrm{p}>0.05\right.$, $\hat{\mathrm{c}}=1.5$ and $\chi^{2}=2.55, \mathrm{p}>0.05, \hat{\mathrm{c}}=0.26$, respectively, where $\hat{c}$ is the overdispersion parameter).

Table 4. Estimated $\beta$ coefficient values and SEs for covariables influencing probabilities of Amazonian manatee occupancy in 2 localities of the Ecuadorian Amazon. D_SET: distance to human settlements; GRASS: area covered by flooded forest; D_RIV: distance to the river mouth

\begin{tabular}{|llrr|}
\hline Survey site & Covariable & $\beta$ & SE \\
\hline Tambococha- & $\psi$ (D_SET) & 6.08 & 8.55 \\
Jatuncocha & $\psi$ (GRASS) & -0.97 & 1.20 \\
& $\psi($ D_RIV) & 2.08 & 3.26 \\
Lagarto River & $\psi($ D_SET) & 0.49 & 0.68 \\
& $\psi($ GRASS) & 0.44 & 0.59 \\
& $\psi$ (D_RIV) & 0.02 & 0.67 \\
\hline
\end{tabular}




\section{DISCUSSION}

The Amazonian manatee Trichechus inunguis is a rare, elusive and cryptic species (Best 1982, 1983, Timm et al. 1986, Rosas 1994, Denkinger 2010, De Souza 2015, Reynolds et al. 2018). Side-scan sonar has proven to be an effective tool for studying Amazonian manatees in Ecuador, with an estimated detection probability of $\sim 0.50$, occupancy estimates of $\sim 0.61$ and number of detection events of 51. Although this study was designed for Amazonian manatees, side-scan sonar is applied much more broadly, including in population surveys of other Amazonian aquatic vertebrates (e.g. pirarucú, caimans), identification of fish spawning beds and habitat mapping (Kaeser \& Litts 2010, Flowers \& Hightower 2013, Yamasaki et al. 2017, Fleming et al. 2018).

The occupancy and population density estimates for the Amazonian manatee reported here are the first for the western Amazon. Encounter rates of Amazonian manatees in the study area (0.08-0.09 records $\mathrm{km}^{-1}$ ) were similar to those reported in a previous effort in the same area using side-scan sonar (0.09-0.15 records $\mathrm{km}^{-1}$; Brice 2014) and lower than encounter rates for the Pacaya River (0.2-0.4 records $\mathrm{km}^{-1}$; Reeves et al. 1996). In terms of estimations of population density, data for the Amazonian manatee is still scarce. Our estimations of population density (0.94-1.09 ind. $\mathrm{km}^{-2}$ ) are significantly lower than those reported for Lago Amanã in Brazil (3.8-7.40 ind. $\mathrm{km}^{-2}$; Best 1983). These differences might be the result of different survey methodologies (Gonzalez-Socoloske \& Olivera-Gomez 2012, Arévalo-González et al. 2014), gradients of human activities (Domning 1982, Rosas 1994, Jiménez 2002, Gonzalez-Socoloske 2007, Mayaka et al. 2013) or different ecological and biogeographical conditions throughout the range of the species (Gaston 2003, Arraut et al. 2010, Satizábal et al. 2012).

Classifying the conservation status of threatened species using tools such as the IUCN Red List (https://www.iucnredlist.org/) is a critical step for identifying species at risk of extinction and for planning conservation actions at different scales (from global to subnational levels). The Amazonian manatee, according to the IUCN, is considered a Vulnerable species (Marmontel et al. 2016). However, the lack of a reliable method to determine abundance and population density has precluded a robust evaluation following Criteria A and E (IUCN 2012). Both criteria (A: reduction in population size; and E: quantitative analysis of probability of extinction) depend on robust estimations of population size as input for monitoring programs and population viability analy- ses. In Ecuador, a country with unstructured and spatially limited monitoring schemes and limited conservation resources, these data requirements have proved challenging to obtain for most species and have led to uncertainties in decision making. In this context, the use of side-scan sonar (coupled with occupancy and distance models) for monitoring Amazonian manatee populations might represent a game changer for the conservation of this species.

As a result of hunting, the present population size of the Amazonian manatee in the study area is believed to be significantly smaller than it was in the past (Timm et al. 1986, Denkinger 2010). However, we lack quantitative evidence to confirm this statement. The population estimations for the Amazonian manatee presented here represent a robust baseline for monitoring population trends in the long term and a standard for measuring the impacts of human activities and the effectiveness of conservation actions. In addition, our data could be used to monitor population changes between low-water and high-water seasons to evaluate habitat use and movement patterns. This would help us determine whether Amazonian manatees in the study area undergo seasonal migrations as they do in varzea habitats, where the flood pulse causes changes in the distribution and population density of terrestrial and aquatic fauna (Bodmer 1990, Fernandes 1997, Utreras et al. 2005, Haugaasen \& Peres 2007, Arraut et al. 2010).

Our occupancy results suggest that the Amazonian manatee is being affected by human activities, which is why its occupancy is lower in areas with higher human activity. The river and lagoon systems of Tambococha-Jatuncocha and the Lagarto River are vital for the conservation of the species in Ecuador; however, these sites face several threats which endanger the long-term survival of the species. Activities such as illegal hunting and habitat loss have caused a drastic decrease of its population, leaving the species close to local extinction (Timm et al. 1986, Denkinger 2010, Utreras et al. 2011). Furthermore, water pollution due to oil spills, incidental capture in fishing nets, use of dynamite and toxic chemicals for fishing and the increasing use of speed boats exacerbate the current situation of the Amazonian manatee in Ecuador (Utreras et al. 2013). In this context, it is important to implement conservation actions with indigenous communities settled near Tambococha-Jatuncocha and the Lagarto River, and in larger settlements along the Napo and Aguarico rivers, to improve their fishing and tourism practices, protect aquatic habitats and control illegal fishing practices, as well as to implement traffic regulations for speed boats. 
The Amazonian manatee population estimates presented here represent a baseline for future research but additional surveys are needed to understand population fluctuations over time. The Ministry of the Environment of Ecuador has published a monitoring protocol to standardize future efforts (Ministerio del Ambiente 2018). Also, an evaluation of population viability in Tambococha-Jatuncocha and the Lagarto River would be required to determine whether these populations will be able to persist over the long term under different deterministic and stochastic scenarios. We recommend the exploration of additional areas, not covered in our surveys, to identify other possible subpopulations in the known range of the manatee in Amazonian Ecuador. Finally, we recommend the use of various survey techniques (e.g. side-scan sonar, environmental DNA) to increase the effectiveness of future research on this species.

Acknowledgements. Our work received financial support from The Gordon and Betty Moore Foundation and The Global Environmental Facility (GEF) through the United Nations Development Programme (UNDP) as part of the Project 'Advancing Landscape Approaches in Ecuador's National Protected Area System to Improve Conservation of Globally Endangered Wildlife' (Project ID 00086648). We thank the Ministry of the Environment of Ecuador for permission to undertake this study (No. 012-16 IC-FAUDNB/MA; No.019-17 IC-FAU-DNB/MA). Protected area officials (Luis Borbor, Luis Tonato and Teófilo Torres) and park rangers provided invaluable support in the field, including staff from Yasuní National Park and Cuyabeno Wildlife Reserve in Ecuador and Güeppí-Sekime National Park in Peru. Daniela Pareja and María Fernanda Solórzano helped with data collection in Tambococha-Jatuncocha. Diana Paredes and Francis Ordoñez provided GIS and cartography support at the office and in the field. Nataly Castelblanco, Miriam Marmotel, Leon Olivera-Gomez, Daniel Gonzalez-Socoloske, Fabiola Corona, Katherine Arévalo, Jenner Rodas, Hilda Perez and Jose Benjamin Morales confirmed the identification of Amazonian manatees in the sonar images. Randall Rubí provided useful comments on early versions of this manuscript.

\section{LITERATURE CITED}

Arévalo-González GK, Castelblanco-Martínez DN, SánchezPalomino P, López-Arévalo HF, Marmontel M (2014) Complementary methods to estimate population size of Antillean manatees (Sirenia: Trichechidae) at Ciénaga de Paredes, Santander, Colombia. J Threat Taxa 6: 5830-5837

* Arraut EM, Marmontel M, Mantovani JE, Novo EMLM, Macdonald DW, Kenward RE (2010) The lesser of two evils: seasonal migrations of Amazonian manatees in the western Amazon. J Zool (Lond) 280:247-256

Arroba Benítez F (2011) Abundancia relativa de las especies de Aligatóridos presentes en el sistema hidrográfico del
Río Yasuní y del Río Lagartococha en la Amazonía Ecuatoriana. BSc thesis, Pontificia Universidad Católica Del Ecuador, Quito

Asanza E (1985) Distribución, biología reproductiva y alimentación de cuatro especies de Alligatoridae, especialmente Caiman crocodilus en la Amazonía del Ecuador. BSc thesis, Pontificia Universidad Católica Del Ecuador, Quito

Best RC (1982) Seasonal breeding in the Amazonian manatee, Trichechus inunguis (Mammalia: Sirenia). Biotropica 14:76-78

* Best RC (1983) Apparent dry-season fasting in Amazonian manatees (Mammalia: Sirenia). Biotropica 15:61-64

Best RC (1984) The aquatic mammals and reptiles of the Amazon. In: Sioli H (ed) The Amazon. Monographiae Biologicae, Springer, Dordrecht, p 371-412

Bodmer RE (1990) Responses of ungulates to seasonal inundations in the Amazon floodplain. J Anim Ecol 6:191-201

Brice CE (2014) The detection of Amazonian manatees (Trichechus inunguis) using side-scan sonar and the effect of oil activities on their habitats in eastern Ecuador. MSc thesis, Nova Southeastern University, Fort Lauderdale, FL

Buckland ST, Anderson DR, Burnham KP, Laake JL, Borchers DL, Thomas L (2001) Introduction to distance sampling: estimating abundance of biological populations. Oxford University Press, Oxford

Burnham KP, Anderson DR (2002) Model selection and multimodel inference: a practical information-theoretic approach. Springer, New York, NY

* Carrillo E, Wong G, Cuarón AD (2000) Monitoring mammal populations in Costa Rican protected areas under different hunting restrictions. Conserv Biol 14:1580-1591

Castelblanco-Martínez DN, dos Reis V, de Thoisy B (2018) How to detect an elusive aquatic mammal in complex environments? A study of the Endangered Antillean manatee Trichechus manatus manatus in French Guiana. Oryx 52:382-392

De Souza DA (2015) Peixe-boi da Amazônia (Trichechus inunguis Natterer 1883): mortalidade e uso do habitat na reserva de desenvolvimento sustentável Piagaçu-Purus, Amazonas, Brasil. MSc thesis, Instituto Nacional de Pesquisas da Amazonia-INPA, Manaus

Denkinger J (2010) Status of the Amazonian manatee (Trichechus inunguis) in the Cuyabeno Reserve, Ecuador. Av Cienc Ing 2:B22-B26

Nomning DP (1982) Commercial exploitation of manatees Trichechus in Brazil c. 1785-1793. Biol Conserv 22: 101-126

Fernandes CC (1997) Lateral migration of fishes in Amazon floodplains. Ecol Freshwat Fish 6:36-44

Fleming PB, Daugherty DJ, Smith NG, Betsill RK (2018) Efficacy of low-cost, side-scan sonar for surveying alligator gars. Trans Am Fish Soc 147:696-703

Flowers HJ, Hightower JE (2013) A novel approach to surveying sturgeon using side-scan sonar and occupancy modeling. Mar Coast Fish 5:211-223

Galacatos K, Barriga-Salazar R, Stewart DJ (2004) Seasonal and habitat influences on fish communities within the lower Yasuni River basin of the Ecuadorian Amazon. Environ Biol Fishes 71:33-51

Gaston KJ (2003) The structure and dynamics of geographic ranges. Oxford University Press, Oxford

* Gerstein ER, Gerstein L, Forsythe SE, Blue JE (1999) The underwater audiogram of the West Indian manatee (Trichechus manatus). J Acoust Soc Am 105:3575-3583 
Gese EM (2001) Monitoring of terrestrial carnivore populations. In: Gittleman JL, Funk SM, Macdonald DW, Wayne RK (eds) Carnivore conservation. Cambridge University Press, Cambridge, p 372-396

Gonzalez-Socoloske D (2007) Status and distribution of manatees in Honduras and the use of side-scan sonar. MS thesis, Loma Linda University, Loma Linda, CA

Gonzalez-Socoloske D, Olivera-Gomez LD (2012) Gentle giants in dark waters: using side-scan sonar for manatee research. Open Remote Sens J 5:1-14

Gonzalez-Socoloske D, Olivera-Gomez LD, Ford RE (2009) Detection of free-ranging West Indian manatees Trichechus manatus using side-scan sonar. Endang Species Res 8:249-257

Haugaasen T, Peres CA (2007) Vertebrate responses to fruit production in Amazonian flooded and unflooded forests. Biodivers Conserv 16:4165-4190

Hines J (2018) PRESENCE v. 12.39. US Geological Survey, Patuxent Wildlife Research Center, Patuxent, MD

Humminbird (2014) Humminbird operations manual, 800 Series $^{\mathrm{TM}}$ and 900 Series $^{\mathrm{TM}}$. Johnson Outdoors, Racine, WI

Isasi-Catalá E, Acosta J, Anchante A, Bianchi G and others (2016) Modelos de ocupación para el monitoreo de la efectividad de estrategias de conservación del área de conservación regional comunal Tamshiyacu TahuayoACRCTT, Loreto-Perú. Ecol Apl 15:61-68

IUCN (2012) IUCN Red List categories and criteria: version 3.1, 2nd edn. IUCN, Gland. https://www.iucnredlist.org/ resources/categories-and-criteria

Jiménez I (2002) Heavy poaching in prime habitat: the conservation status of the West Indian manatee in Nicaragua. Oryx 36:272-278

Kaeser AJ, Litts TA (2010) A novel technique for mapping habitat in navigable streams using low-cost side scan sonar. Fisheries (Bethesda, Md) 35:163-174

MacKenzie DI, Bailey LL (2004) Assessing the fit of siteoccupancy models. J Agric Biol Environ Stat 9:300-318

MacKenzie DI, Nichols JD, Lachman GB, Droege S, Andrew Royle J, Langtimm CA (2002) Estimating site occupancy rates when detection probabilities are less than one. Ecology 83:2248-2255

MacKenzie DI, Nichols JD, Royle JA, Pollock KH, Hines JE, Bailey LL (2006) Occupancy estimation and modeling: inferring patterns and dynamics of species occurrence. Academic Press, Oxford

* Marmontel M, De Souza D, Kendall S (2016) Trichechus inunguis. The IUCN Red List of Threatened Species 2016: e.T22102A43793736. http://dx.doi.org/10.2305/ IUCN.UK.2016-2.RLTS.T22102A43793736.en (accessed 16 Dec 2019)

Mayaka TB, Awah HC, Ajonina G (2013) Conservation status of manatee (Trichechus senegalensis Link 1795) in lower Sanaga basin, Cameroon: an ethnobiological assessment. Trop Conserv Sci 6:521-538

Ministerio del Ambiente (2018) Protocolo para el censo y monitoreo del manatí amazónico (Trichechus inunguis). Proyecto Paisajes Vida Silvestre, Ministerio del Ambiente, Wildlife Conservation Society, Quito

Editorial responsibility: Helene Marsh, Townsville, Queensland, Australia
Pourrut P, Pouyaud B (1995) El agua en el Ecuador: clima, precipitaciones, escorrentía. Corporacion Editora Nacional, ORSTOM, Colegio de Geógrafos del Ecuador, Quito

Reeves RR, Leatherwood S, Jefferson TA, Curry BE, Henningsen T (1996) Amazonian manatees, Trichechus inunguis, in Peru: distribution, exploitation, and conservation status. Interciencia 21:246-254

* Reyna-Hurtado R, Tanner GW (2005) Habitat preferences of ungulates in hunted and nonhunted areas in the Calakmul Forest, Campeche, Mexico. Biotropica 37:676-685

Reynolds JE III, Powell JA, Keith Diagne LW, Barton SL, Scolardi KM (2018) Manatees: Trichechus manatus, T. senegalensis, and T. inunguis. In: Würsig B, Kovacs KM, Thewissen J (eds) Encyclopedia of marine mammals, 3rd edn. Academic Press, London, p 558-566

* Rosas FCW (1994) Biology, conservation and status of the Amazonian manatee Trichechus inunguis. Mammal Rev 24:49-59

* Satizábal P, Mignucci-Giannoni AA, Duchêne S, CaicedoHerrera D and others (2012) Phylogeography and sexbiased dispersal across riverine manatee populations (Trichechus inunguis and Trichechus manatus) in South America. PLOS ONE 7:e52468

Sierra R (1999) Propuesta preliminar de un sistema de clasificación de vegetación para el Ecuador continental. Inefan/Gef-Birf y Ecociencia, Quito

* Thomas L, Buckland ST, Rexstad EA, Laake JL and others (2010) Distance software: design and analysis of distance sampling surveys for estimating population size. J Appl Ecol 47:5-14

* Timm RM, Albuja L, Clauson BL (1986) Ecology, distribution, harvest, and conservation of the Amazonian manatee Trichechus inunguis in Ecuador. Biotropica 18: 150-156

Tirira DG (2011) Libro Rojo de los mamíferos del Ecuador, 2nd edn. Fundación Mamíferos y Conservación, Pontificia Universidad Católica del Ecuador, Ministerio del Ambiente, Quito

Tirira DG (2017) A field guide to the mammals of Ecuador. Editorial Murciélago Blanco, Quito

* Utreras B V, Suárez E, Zapata-Ríos G, Lasso G, Pinos L (2005) Dry and rainy season estimations of giant otter, Pteronura brasiliensis, home range in Yasuní National Park, Ecuador. Lat Am J Aquat Mamm 4:191-194

Utreras V, Denkinger J, Tirira DG (2011) Manatí amazónico (Trichechus inunguis). In: Tirira DG (ed) Libro Rojo de los mamíferos del Ecuador, 2nd edn. Fundación Mamíferos y Conservación, Pontificia Universidad Católica del Ecuador, Ministerio del Ambiente, Quito, p 66-68

Utreras V, Trujillo F, Usma JS (2013) Plan de acción para la conservación de los mamíferos acuáticos de la Amazonía ecuatoriana. Ministerio de Ambiente, Wildlife Conservation Society, Fundación Omacha, World Wildlife Fund, Quito

Yamasaki S, Tabusa T, Iwasaki S, Hiramatsu M (2017) Acoustic water bottom investigation with a remotely operated watercraft survey system. Prog Earth Planet Sci $4: 25$

Submitted: March 20, 2020; Accepted: November 10, 2020 Proofs received from author(s): February 5, 2021 